\title{
Strategi Membangun Karakter Peduli Sesama di Kalangan Mahasiswa Teologi Berdasarkan Filipi 2:1-8
}

\author{
Nurnilam Sarumaha ${ }^{1}$, Novie Deisy Pasuhuk ${ }^{2}$ \\ ${ }^{1,2}$ Prodi Pendidikan Agama Kristen, Sekolah Tinggi Teologi Pelita Bangsa, Jakarta \\ ${ }^{1}$ nurnilam150676@gmail.com, ${ }^{2}$ novie.pasuhuk@gmail.com
}

\begin{abstract}
One attitude of the Christian faith is caring for others, as a reflection of caring character for oneself. However, the lives of students of Theological College (STT) cannot fully practice caring attitudes towards others. This research is qualitative research with a descriptive analysis method about the concept of caring for others according to Philippians 2: 1-8 that is applied in the lives of STT Pelita Bangsa students, Jakarta. The concept and understanding of caring attitudes were explored hermeneutically from the Philippian text, then synchronized with the situation of the students through observation and in-depth interviews. Research results in the form of recommendations, such as the need for models or examples from leaders; a kind of clear and written rules must be made; procurement of special room for counseling room.
\end{abstract}

Keywords: care to each other; caring character; Philippians 2; theological students

\begin{abstract}
Abstrak: Salah satu sikap iman Kristen adalah mempedulikan orang lain, sebagai refleksi karakter peduli terhadap diri sendiri. Namun demikian, kehidupan mahasiswa Sekolah Tinggi Teologi (STT) tidak sepenuhnya dapat mempraktikkan sikap kepedulian terhadap sesama tersebut. Penelitian ini merupakan penelitian kualitatif dengan metode analisis deskriptif tentang konsep peduli terhadap sesama menurut Filipi 2:1-8 yang diterapkan dalam kehidupan mahasiswa STT Pelita Bangsa, Jakarta. Konsep dan pemahaman tentang sikap peduli digali secara hermeneutis dari teks Filipi, lalu disinkronisasi dengan keadaan para mahasiswa melalui observasi dan wawancara mendalam. Hasil penelitian berupa rekomendasi, seperti: perlu adanya model atau keteladanan dari para pemimpin; perlu dibuatkan semacam peraturan-peraturan yang jelas dan tertulis; pengadaan ruang khusus untuk ruangan konseling.
\end{abstract}

Kata kunci: Filipi 2; karakter peduli; mahasiswa teologi; peduli sesama

\section{Pendahuluan}

Dalam Kamus Besar Bahasa Indonesia, istilah peduli merupakan kata kerja yang berarti mengindahkan, memperhatikan atau menghiraukan. ${ }^{1}$ Peduli berarti suatu sikap yang dibangun oleh seseorang terhadap dirinya sendiri agar ia mampu mengindahkan, memperhatikan atau menghiraukan hal-hal yang berada di luar dirinya. Hal-hal tersebut bisa saja berupa benda-benda atau makhluk hidup yang ada di sekitarnya. Peduli adalah bagaimana seseorang memperlakukan lingkungannya.

Sikap Peduli merupakan salah satu dari 18 nilai pembentuk karakter yang telah dipublikasikan oleh Pusat Kurikulum Badan Penelitian dan Pengembangan Kementrian

${ }^{1}$ Tim Redaksi, Kamus Besar Bahasa Indonesia Pusat Bahasa (Jakarta: Gramedia, 2013), 657. 
Pendidikan Nasional dalam buku Pedoman Pelaksanaan Pendidikan Karakter tahun $2011 .^{2}$ Dalam sebuah diskusi yang diadakan di Kementrian Pendidikan Nasional, sepakat memilih nilai inti (core values) yang akan dikembangkan dalam implementasi pendidikan karakter di Indonesia yaitu cerdas, jujur, tangguh dan peduli sosial. ${ }^{3}$ Peduli sosial yang dimaksudmerupakan suatu sikap dan tindakan untuk memperhatikan atau menghiraukan orang lain. Peduli sosial adalah sikap dan perbuatan yang selalu ingin memberi bantuan kepada orang lain dan masyarakat yang membutuhkan. ${ }^{4}$ Dalam iman Kristen, sikap peduli terhadap sesama terangkum dalam hukum kasih yaitu: "Kasihilah sesamamu manusia seperti dirimu sendiri” (Mat. 22:39) Paulus, dalam tulisannya kepada jemaat Filipi juga menekankan bahwa setiap orang seharusnya tidak hanya memperhatikan kepentingannya sendiri melainkan juga kepentingan orang lain (Flp. 2:4). Peduli terhadap sesama bukan saja karena pemerintah menggalakkan pembangunan karakter, tetapi utamanya karena prinsip iman Kristen adalah mempedulikan orang lain berarti peduli dengan diri sendiri.

Sebagai mahasiswa di Sekolah Tinggi Teologi setiap pribadi merupakan orangorang yang telah menjawab panggilan Tuhan, yang berasal dari berbagai latar belakang ekonomi, budaya dan suku yang berbeda. Dengan latar belakang kehidupan yang beragam, mereka tinggal dan hidup bersama di sebuah tempat (asrama) yang disediakan oleh lembaga sekolah tinggi teologi. Demikian juga yang terjadi di lingkungan Sekolah Tinggi Teologi (STT) Pelita Bangsa, Jakarta. Hanya saja, dalam kehidupan bersama ini, tidak berjalan mulus karena adanya masalah. Dalam kehidupan bersama di asrama, mahasiswa yang berasal dari berbagai latar belakang yang beragam memiliki kesulitan untuk dapat beradaptasi satu dengan yang lain. Berbagai persoalan muncul, sehingga tidak jarang menimbulkan perselisihan di antara mereka.

Salah satu masalah utama yang terlihat adalah kurangnya kepedulian terhadap sesama. Sebagai contoh, saat hujan turun, jemuran tidak akan diangkat dan dibiarkan basah, karena merasa itu bukan milik mereka. Ketika ada teman yang sakit, bersikap tidak peduli karena merasa bukan bagian dari tanggung jawabnya dan ada tim pemerhati dari Badan Eksekutif Mahasiswa (BEM) yang bertanggung jawab jika ada teman-teman mereka yang sakit. Membiarkan sampah bertebaran dimana-mana karena merasa mereka bukan petugas piket/petugas kebersihan pada saat itu. Di kelas, misalnya saat dosen masuk kelas, kursi dibiarkan berantakan, papan tulis tidak dibersihkan karena merasa itu tugas ketua kelas.

Penelitian ini bertujuan mendeskripsikan strategi pembangunan karakter peduli terhadap sesama yang digunakan kepada mahasiswa STT Pelita Bangsa, dan diharapkan, secara teoritis, mampu menolong mahasiswa STT Pelita Bangsa dalam konsep atau teoriteori tentang pembangunan karakter sehingga mampu meningkatkan rasa peduli terhadap

\footnotetext{
${ }^{2}$ Kementrian Pendidikan Nasional: Badan Penelitian dan Pengembangan Pusat Kurikulum dan Perbukuan, Panduan Pelaksanaan Pendidikan Karakter, Jakarta: 2011, 8.

${ }^{3}$ Muchlas Samani dan Hariyanto, Konsep dan Model Pendidikan Karakter, (Jakarta: Rosda Jaya, 2015), 134. 2012), 7.

${ }^{4}$ Retno Listyarti, Pendidikan Karakter Dalam Metode Aktif, Inovatif dan Kreatif, Jakarta: Esensi,
} 
teman-teman dan orang lain pada umumnya. Pihak kampus dapat mengembangkan konsep sebuah kurikulum pembangunan karakter berdasarkan pada Alkitab atau Firman Tuhan. Sedangkan secara praktis, hasil penelitian diharapkan: pertama, menjadi sebuah masukan kepada pihak kampus baik pimpinan maupun para dosen agar dapat memberikan perhatian khusus terhadap tingkat kepedulian mahasiswa sebagai bagian dari pembentukan karakter mahasiswa, dalam rangka meningkatkan kualitas dan kuantitas khususnya kampus STT Pelita Bangsa dan kampus yang lain pada umumnya. Kedua, menjadi masukan bagi mahasiswa untuk menjadi pribadi yang lebih berkarakter, menjadi orang yang memiliki tingkat kepedulian yang tinggi terhadap sesamanya. Ketiga, masukan bagi setiap orang yang membaca tulisan ini, mengetahui betapa pentingnya pembangunan karakter peduli terhadap sesama.

Tema tentang membangun karakter Kristen merupakan pembahasan yang cukup populer, seperti karakteristik Pentakostalisme yang ditunjukkan oleh para jemaat mulamula di dalam Kisah Para Rasul. ${ }^{5}$ Karakter itu juga yang pada akhirnya menjadi contoh bagi orang percaya pada masa kini. Demikian halnya jika hal tersebut diterapkan pada membangun karakter mahasiswa teologi. Desti Samarenna pernah membagikan tentang membangun keteladanan mahasiswa di sekolah tinggi teologi sebagai pemimpin. ${ }^{6}$ Fokus dalam penelitian ini adalah pada karakter peduli mahasiswa teologi, yang dapat dirangkum dengan pertanyaan: Bagaimanakah cara membangun karakter peduli terhadap sesama diantara mahasiswa Sekolah Tinggi Teologi Pelita Bangsa berdasarkan eksposisi surat Filipi 2:1-8?

\section{Metode Penelitian}

Metode penelitian adalah cara atau prosedur yang digunakan untuk mengetahui sesuatu. Sugiyono mengartikannya sebagai cara ilmiah untuk mendapatkan data dengan tujuan dan kegunaan tertentu. ${ }^{7}$ Penelitian ini merupakan penelitian kualitatif yang dilakukan terhadap mahasiswa Sekolah Tinggi Teologi (STT) Pelita Bangsa, Jakarta, yang beralamatkan di Jl. Pasar Baru Selatan No. 25, Jakarta Pusat. Penelitian ini mengguna-kan metode analisis deskriptif, berupa kajian kitab suci tentang konsep peduli terhadap sesama yang diaplikasikan dalam kehidupan mahasiswa STT Pelita Bangsa. Peneliti menggunakan instrumen observasi untuk mendapatkan gambaran secara umum yang terjadi dalam situasi sosial mahasiswa STT Pelita Bangsa; bagaimana mereka bersikap terhadap sesama. Penelitian ini memerlukan data dari beberapa partisipan yagn telah ditentukan demi memperoleh gambaran faktual terhadap permasalahan yang akan diteliti. Prosedur pengambilan data sebagai berikut: menentukan narasumber atau partisipan, menentukan lokasi pengambilan data dan menetapkan teknik pengambilan data.

\footnotetext{
${ }^{5}$ Harls Evan Siahaan, "Karakteristik Pentakostalisme Menurut Kisah Para Rasul,” DUNAMIS (Jurnal Teologi dan Pendidikan Kristiani) 2, no. 1 (2017): 12-28.

${ }^{6}$ Desti Samarenna and Harls Evan R Siahaan, "Memahami Dan Menerapkan Prinsip Kepemimpinan Orang Muda Menurut 1 Timotius 4:12 Bagi Mahasiswa Teologi," BIA': Jurnal Teologi dan Pendidikan Kristen Kontekstual 2, no. 1 (2019): 1-13, http://www.jurnalbia.com/index.php/bia.

${ }^{7}$ Sugiono, Metode Penelitian Kombinasi (Mixed Methode), (Bandung: Alfabeta, 2011), 3.
} 
Tabel 1: Narasumber/Partisipan/Informan Penelitian

\begin{tabular}{|l|l|}
\hline NAMA & \multicolumn{1}{|c|}{ JABATAN/PEKERJAAN } \\
\hline Dr. Handreas Hartono, M. Pd. K & Dosen/Gembala Sidang GSY Pasar Baru \\
\hline Maria Magdalena, M. Th & Dosen/Waket III STTPB/Kepala Asrama \\
\hline Susi & Mahasiswa Sem. III tinggal di asrama \\
\hline Lodia & Mahasiswa Sem. VII tinggal di asrama \\
\hline Tabita Malau & Mahasiswa Sem. V tinggal di asrama \\
\hline Desta Lenta Zebua & Mahasiswa/Bid. kerohanian asrama putri \\
\hline Michael Hung Ifander Parbosky & Mahasiswa /Ketua BEM STTPB \\
\hline Yuliana Yesika & Mahasiswa Sem. VII tinggal di asrama \\
\hline Mesrita Fransiska Waruwu & Mahasiswa/Mantan ketua asrama putri \\
\hline Daniel Yohanes Koyansow & Mahasiswa Sem. IX \\
\hline Ritania Kasewa & Mahasiswa Sem. V tinggal di asrama \\
\hline Yambres Biu & Mahasiswa Sem. III tinggal di asrama \\
\hline TOTAL & 12 Orang \\
\hline
\end{tabular}

\section{Analisis Filipi 2:1-8}

Inti dari penelitian ini adalah bagaimana strategi untuk membangun karakter peduli mahasiswa berdasarkan pemahaman teks pada Filipi 2:1-8. Dalam suratnya kepada jemaat Filipi, Rasul Paulus menguraikan betapa pentingnya karakter peduli terhadap sesama. Paulus menekankan pentingnya kesatuan roh, kesatuan hati dan juga pentingnya meneladani Kristus dalam kehidupan bersama.

\section{Karakter Peduli Terhadap Sesama dalam Filipi 2:1-8}

Karakter menurut Kamus Besar Bahasa Indonesia adalah sifat-sifat kejiwaan, akhlak atau budi pekerti yang membedakan seseorang dengan yang lain; tabiat; watak. ${ }^{8}$ Karakter merupakan sosok asli diri, kualitas diri, perangai, tabiat dan watak, kepribadian dalam diri, kecenderungan, hasrat/keinginan/kehendak dalam diri, kekuatan dasar dari moral, serta gabungan dari kualitas diri kita. ${ }^{9}$ Dalam pembentukan kualitas seseorang, peran karakter memegang peranan penting, karena sesungguhnya karakter menempatkan baik atau tidaknya seseorang. Dapat dikatakan bahwa karakter merupakan ciri khas yang melekat pada diri seseorang, sehingga ia mampu dibedakan dari orang lain.

Seperti yang telah dijelaskan dalam bab sebelumnya, ada beberapa faktor yang membentuk karakter atau kepribadian seseorang, salah satunya adalah karakter peduli terhadap sesama. Karakter peduli terhadap sesama merupakan suatu sikap atau tabiat yang terdapat dalam diri seseorang yang selalu fokus mementingkan kepentingan orang lain di atas kepentingan dirinya sendiri. Memperhatikan orang lain bukan untuk mencari kepuasan diri sendiri ataupun melepaskan orang lain dari tanggung jawabnya, melainkan bentuk kepedulian yang diwujudkan, untuk meringankan beban orang lain. Mau memperlakukan

${ }^{8}$ Tim Redaksi, Kamus BesarBahasa Indonesia, (Jakarta: Balai Pustaka, 1989), 389.

${ }^{9}$ Chandra Suwondo, Karakter Keindahan Sejati Dari Manusia, (Jakarta: Metanoia, 2007), 1-2. 
orang lain dengan penuh kebaikan dan kedermawanan serta memberi bantuan ketika seseorang memerlukan bantuan.

Dalam iman Kristen, dasar pembentuk karakter seseorang adalah firman Tuhan. Ketika seseorang telah mengalami pertobatan, percaya kepada Yesus sebagai Tuhan dan Juruselamat secara pribadi, maka karakter yang dihasilkan adalah karakter yang berasal dari buah pertobatan (Mat. 3:8). Ketika orang Kristen melakukan kebaikan, tidak hanya karena keinginan diri semata, melainkan kesadaran bahwa telah menerima kebaikan Allah terlebih dahulu.

Paulus menjabarkan beberapa istilah yang berhubungan dengan karakter peduli terhadap sesama, yaitu:

Pertama, sehati sepikir dalam ayat 1-2. Istilah sehati sepikir dalam ayat ini berasal

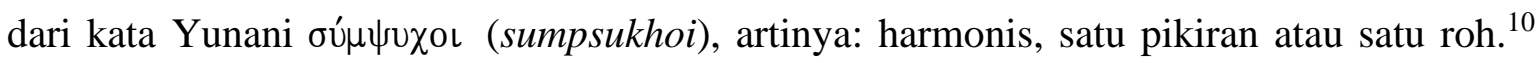

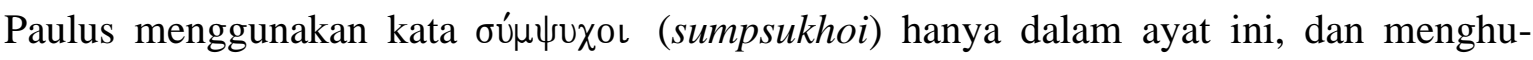

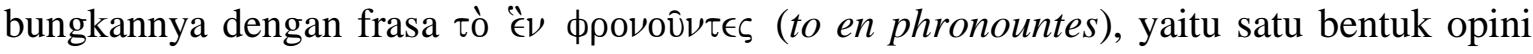

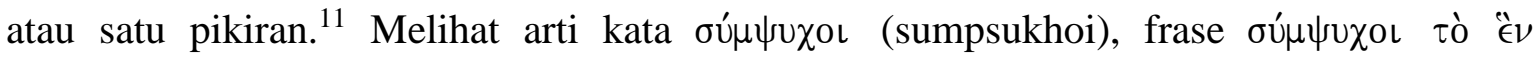
$\phi \rho о \nu 0 \hat{\nu} \tau \epsilon \varsigma$ bukan hanya sekadar bentuk nasihat yang disampaikan Paulus agar jemaat Filipi, khususnya Euodia dan Sintikhe selalu harmonis dan satu pikiran, lebih dari pada itu, mereka harus memiliki kesatuan roh (Fil. 4:1). Dasar dari keharmonisan dan kesatuan pikiran adalah kesatuan roh. Tanpa kesatuan roh, maka keharmonisan dan kesatuan pikiran mustahil terjadi. Keegoisan akan lebih menguasai pikiran, dan hal itu yang terjadi terhadap Euodia dan Sintikhe. Euodia dan Sintikhe merupakan diaken dan termasuk dalam kepemimpinan jemaat. Mereka dinasihati Paulus karena terlibat dalam perselisihan yang serius sehingga dapat menimbulkan perpecahan dalam jemaat di Filipi. ${ }^{12}$ Sebagai hamba-hamba Tuhan yang terpilih menjadi pemimpin dalam jemaat, wajib memiliki kepedulian terhadap satu dengan yang lain, mengutamakan keharmonisan, kesatuan pikiran, kesatuan tujuan dan kesatuan roh.

Kedua, rendah hati (3-4). Dalam Filipi 2:3, istilah rendah hati berasal dari kata Yunani $\tau \hat{n} \tau \alpha \pi \epsilon \iota \nu \circ \phi \rho \sigma u ́ v \eta ̣$ (te tapeinophrosune) artinya kerendahan hati, kesederhanaan. ${ }^{13}$ Istilah ini digunakan sebanyak 7 kali dalam Alkitab. Paulus menggunakan istilah ini dalam kitab Filipi sebagai cara praktis untuk menasehati jemaat Filipi agar memiliki kepedulian satu dengan yang lain. Paulus menegaskan bahwa kerendahan hati setiap orang akan berdampak bagi persekutuan dan persatuan. Lawan kerendahan hati adalah kesombongan. Ketika kesombongan lebih mendominasi karakter seseorang, kecenderungan sikap adalah mementingkan diri sendiri dan keinginan selalu dipuji-puji. Menurut Foulkes, mencari kepentingan sendiri dan kesombongan adalah musuh dari persekutuan dan penghalang bagi persatuan. Oleh karena itu, penting untuk lebih mengutamakan orang lain ketimbang diri

\footnotetext{
${ }^{10}$ Sakae Kubo, A Reader's Greek - English Lexicon Of The New Testament, (Michigan: Andrews Univercity Press, 1973), 189.

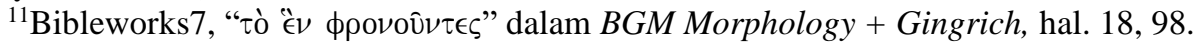

${ }^{12}$ Samuel Benyamin Hakh, Perjanjian Baru, Sejarah, Pengantar dan Pokok-Pokok Teologisnya, (Bandung: Bina Media Informasi, 2010), 191.

${ }^{13}$ Bibleworks7, 196.
} 
sendiri serta harus membiasakan diri untuk berpikir dan berbicara mengenai kepentingan orang lain, jangan hanya kepentingan diri sendiri. ${ }^{14}$

Kerendahan hati dapat membawa seseorang pada kepekaan hati, yaitu kemampuan untuk merasakan apa yang dirasakan oleh orang lain. Mampu menyingkirkan kesombongan dan memperlakukan orang lain dengan rasa hormat dan kesopanan yang wajar. Kepekaan hati memampukan seseorang menganggap penting kepentingan orang lain dibandingkan dengan kepentingannya sendiri.

\section{Strategi Membangun Karakter Peduli Terhadap Sesama}

Dalam membangun karakter peduli terhadap sesamadibutuhkan sebuah strategi. Strategi adalah alat untuk mencapai tujuan yang berdampak pada keberhasilan atau kesuksesan. Dalam Kamus Besar Bahasa Indonesia, strategi diartikan sebagai siasat perang, ilmu siasat perang, tempat yang baik untuk siasat perang atau rencana yang cermat mengenai kegiatan untuk mencapai sasaran khusus. ${ }^{15}$ Sehubungan dengan penelitian ini, arti yang tepat untuk mengartikan istilah strategi adalah ilmu dan seni yang menggunakan sumber daya manusia dan rencana yang cermat untuk menemukan formula atau peraturan yang baku dalam membangun kepedulian terhadap sesama di lingkungan mahasiswa STT Pelita Bangsa.

Pertama, mengutamakan kesatuan roh (Fil. 2:1-2). Tinggal dalam sebuah komunitas atau kelompok, dimana orang-orangnya berasal dari berbagai latar belakang suku, bahasa dan adat istiadat yang berbeda, membutuhkan adaptasi atau penyesuaian diri. Untuk mewujudkannya, Paulus menekankan agar setiap orang mau hidup dalam kesatuan roh atau kesatuan rohani. Kesatuan rohani memungkinkan orang-orang memiliki keharmonisan dalam hubungan, kesehatian dan menerima kekurangan dan kelebihan orang-orang yang ada dalam komunitasnya. Kesatuan rohani penting, mengingat banyak orang - bahkan orang-orang Kristen tidak terkecuali, hidup hanya untuk menciptakan kesan baik kepada orang lain atau untuk menyenangkan diri sendiri. ${ }^{16}$ Dengan adanya kesatuan rohani, maka akan mempermudah terjalinnya kerja sama, saling mengasihi, saling melayani, saling menolong menanggung beban, saling mengampuni, saling mendoakan, dan lain-lainnya.

Kedua, mengutamakan kepekaan hati (Fil. 2:3-4). Tidak semua orang dapat memiliki kepekaan hati, tetapi orang yang memiliki kepekaan hati berarti memiliki kerendahan hati. Dalam ayat ini, dengan jelas Paulus menegaskan bahwa hanya orang yang yang memiliki kepekaan hati mampu mementingkan orang lain di atas kepentingannya sendiri.

Dalam Kisah Para Rasul 17:16, dikatakan bahwa Paulus merasa sangat sedih hatinya karena melihat kota Atena yang penuh dengan patung-patung berhala. Frase "sangat sedih hatinya" merupakan terjemahan dari kata Yunani $\pi \alpha \rho \omega \xi \dot{v} v \in \tau$, berasal dari kata $\pi \alpha \rho \circ \xi u ́ v \omega$

\footnotetext{
${ }^{14}$ F. Foulkes, "Filipi" dalam: Tafsiran Alkitab Masa Kini 3: Matius - Wahyu, (Jakarta: Yayasan Komunikasi Bina Kasih/OMF, 1999), 621.

${ }^{15}$ Tim Redaksi, Kamus BesarBahasa Indonesia, 859.

${ }^{16}$ Anonimus, Alkitab Penuntun Hidup Berkelimpahan Seri: Life Application Study Bible, (Malang: Gandum Mas, 2014) 2533.
} 
artinya (mudah) tersinggung, bergejolak. ${ }^{17}$ Paulus mengalami gejolak perasaan karena hatinya peka melihat keadaan kota Atena yang penuh berhala. Dalam Alkitab Penuntun Hidup Berkelimpahan, digambarkan bahwa kesedihan hati Paulus adalah emosi kuat yang datang tiba-tiba. Paulus dipenuhi perasaan marah dan sedih sekaligus, melihat orang-orang yang secara rohani menghilang dibutakan oleh Iblis dan terjebak oleh budaya kafir. ${ }^{18}$ Bahkan Yesus sendiri juga pernah merasakan kesedihan yang mendalam. Saat Yesus ditangkap, dianiaya (dicambuk) dan disalibkan, tidak menangis dan sedih, tetapi ketika orang-orang di Yerusalem tidak mengerti kebenaran, Yesus menangis dan merasakan kesedihan yang mendalam (Luk. 19:41). Kepekaan hati akan menuntun seseorang rela berkorban dan mau mengulurkan tangan untuk menolong orang lain.

Ketiga, menjadikan kristus sebagai teladan dalam hidup bersama (Fil. 2:5-8). Dalam pembahasan, khususnya ayat 5-8 menjelaskan bagaimana Yesus bersedia melepaskan hak-hak-Nya demi menaati Allah dan melayani manusia. Sehubungan dengan kepedulian terhadap sesama, Yesus memberi teladan karakter dalam beberapa hal: teladan kerendahan hati (Fil. 2:8); teladan kemurahan hati (2 Kor. 8:9); teladan tidak mencaci maki (Ro. 12:14); teladan kesabaran (Ro. 12:12).

\section{Hasil dan Pembahasan}

Penelitian ini menggunakan instrumen wawancara untuk memperoleh data tentang karakter peduli mahasiswa STT Pelita Bangsa, Jakarta. Hasil wawancara yang dilakukan diuraikan dalam beberapa poin berikut:

Berdasarkan hasil wawancara dengan narasumber terutama mahasiswa, peneliti menemukan menemukan data-data yang terkait dengan penelitian ini yaitu strategi yang diperlukan untuk membangun karakter peduli diantara sesama mahasiswa STT Pelita Bangsa, Hal pertama yang ditanggapi atau diresponi sama oleh semua narasumber adalah tentang pentingnya karakter peduli di era globalisasi ini. Kenapa? karena kita tidak hidup sendiri melainkan bersama-sama dan karena peduli adalah sesuai dengan ajaran firman Tuhan. Menyadari bahwa karakter peduli itu penting maka tentunya kepedulian itu benarbenar dirasakan oleh sesamanya sehingga bukan hanya sekedar slogan. Di sini peneliti mendapat jawaban dari narasumber tentang siapa sesama itu yaitu teman-teman di asrama atau di kampus, para dosen, tenaga administrasi, saudara seiman atau orang percaya, orang tua, saudara yang tidak seiman atau orang yang ada disekitar kita dan mereka yang membutuhkan bantuan kita.

Para narasumber memahami betul tentang apa karakter peduli itu, mereka bisa merinci seperti: mempunyai hati dan pikiran seperti Kristus untuk saling mengasihi, saling membantu berbagi sesuatu kepada yang tidak punya apa-apa. Intinya mengamalkan dan menanamkan kasih yang Tuhan Yesus ajarkan itu didalam diri kita. Dalam rangka membangun karakter peduli diantara mahasiswa maka beberapa narasumber, khususnya mahasiswa berpendapat bahwa harus mau belajar dulu pengenalan yang benar akan Kristus

\footnotetext{
${ }^{17}$ Hasan Sutanto, $\pi \alpha \rho \circ \xi u ́ v \omega$ dalam:Perjanjian Baru Interlinear Yunani-Indonesia dan Konkordansi Perjanjian Baru, Jl. 2, (Jakarta: Lembaga Alkitab Indonesia, 2006), 615.

${ }^{18}$ Anonimus, Alkitab Penuntun Hidup Berkelimpahan Seri: Life Application Study Bible, 2311.
} 
karena menurut mereka Kristus adalah seorang pribadi yang sempurna yang memberikan keteladanan soal kepedulian. Tanpa pengenalan yang benar akan Kristus maka kecil sekali kemungkinan untuk seseorang dapat menyatakan rasa peduli kepada orang lain. Yang berikut adalah mereka perlu saling mengenal satu sama lain bagaimana psikologi/ kepribadian teman-teman mereka sekaligus juga menanamkan nilai-nilai persaudaraan tanpa memandang dari suku mana.

Selanjutnya dikatakan bahwa untuk membangun karakter peduli maka harus memiliki kepekaan pada lingkungan sekitar misalnya dengan melayani sambil memperhatikan mereka satu persatu dengan cara memberikan pertolongan berupa nasehat, masukan yang baik, menegur, membangun dan memotivasi, mengarahkan kalau ada yang salah, berbaur dan berbagi sesuatu dengan yang lain suku serta memberi teladan dalam soal etika, moral, nilai juga berusaha untuk tidak sombong. Hal ini juga diperkuat dengan narasumber lain yaitu para dosen yang juga merangkap sebagai gembala sidang dari Gereja Sungai Yordan dimana para mahasiswa STT Pelita Bangsa beribadah dan melayani dan Waket III bidang kemahasiswaan dan pelayanan, sekaligus kepala asrama. Mereka memberi pendapat bahwa dalam rangka membangun karakter peduli diantara mahasiswa maka sebagai dosen mereka selalu mengawasi para mahasiswa supaya tidak menggunakan bahasa daaerah masing-masing, memberikan motivasi, memberikan teladan seperti membersihkan sampah-sampah, memberikan makanan, obat, bahkan membuat kelompok pemuridan.

Ada beberapa faktor yang menjadi penyebab mahasiswa bisa dan tidak bisa menyatakan rasa pedulinya kepada orang lain. Penyebab mahasiswa bisa saling peduli karena pertama bisa menerima diri sendiri, yang kedua sudahtaukebenaran, ketiga mulai dari diri sendiri ada kemauan untuk peduli, terketuk hati, merasa sepenanggungan karena berasal dari satu daerah, dan terakhir bisa menerima keadaan / karakter orang lain. Dalam menyatakan rasa peduli, mereka sudah mulai dengan hal-hal yang sederhana seperti misalnya; ada teman yang bilang kepada kepada temannya yang lain, kamu mau titip apa saya mau pergi beli makanan. Jadi sebenarnya menyatakan rasa peduli itu bukan harus dengan sesuatu yang besar tapi bisa dimulai dari hal yang kecil dan sederhana. Dan juga memperlakukan kasih itu harus adil yaitu tidak memandang bulu. Sedangkan faktor yang membuat mereka tidak bisa menyatakan rasa saling peduli karena tidak bisa menerima diri sendiri sehingga sulit untuk bisa menerima keadaan orang lain dan akibatnya juga sulit untuk peduli, asyik bermain handphone terus sehingga tidak ada kepekaan, egois hanya memikirkan diri sendiri. Ada pula yang memiliki latar belakang kehidupan yang mungkin kurang baik dimasa lalu, dan juga ada yang belum mengenal pribadi Yesus.

Penyebab lainnya adalah faktor suku. Ada sebagian mahasiswa yang masih dikotak-kotakkan oleh suku/bahasa, masih suka bawa-bawa adat dan karakter suku mereka, ada yang belum mengerti satu sama lain dan ada juga yang tergantung pada situasi. Jadi dengan kata lain situasi menentukan seseorang untuk menyatakan rasa pedulinya kepada orang lain. Tidak demikian dengan pendapat dari beberapa dosen yang diwawancarai peneliti. Sebagai dosen mereka tidak membeda-bedakan teman atau maha- 
siswa dari suku mana- suku mana. Sama sekali tidak pernah terpikir masalah suku/ tidak membeda-bedakan. Alasannya karena kita ada dalam satu negara, dimana masing-masing suku itu punya suatu keunikan, punya suatu keindahan . Dari hasil pengamatan salah satu dosen mengatakan mungkin ada mahasiswa yang masih membeda-bedakan suku tapi itu sedikit sekali atau hanya sebagian kecil dan itu mungkin ada pada mereka yang baru masuk semester 1 karena mereka baru datang dan belum banyak bergaul dan mengenal yang lain. Oleh sebab itu mereka harus diberi pengetahuan tentang penerimaan diri sehingga mereka dapat menerima orang lain. Dengan demikian mereka dapat saling peduli satu sama lain.

Situasi dan kondisi yang terlihat dimahasiswa STT Pelita Bangsa menurut beberapa narasumber sudah lumayan baik. Terlihat lebih dewasa, lebih mandiri, lebih peduli, lebih peka, saling membela, kayak saudara. Saling membangun, saling menegur, saling mengarahkan kalau ada yang salah. Tapi ada juga beberapa yang kesadaran kepeduliannya itu tipis. Ada beberapa persen yang memiliki karakter yang perlu diperhatikan, seperti cuek gitu, tidak sesuai dengan apa yang di pelajari dikampus dan tidak sesuai dengan apa yang firmanTuhan sampaikan.

Beberapa bukti kepedulian yang mereka pernah rasakan / alami di asrama yaitu ada yang mendukung dalam doa, memotivasi teman yang malas belajar supaya terus maju dan mau membimbing bahkan ada yang meminjamkan laptop agar teman dapat membuat tugas. Begitu juga di saat sakit ada yang menolong mendampingi serta membawa ke dokter/ Rumah Sakit, di saat tertutup pikiran ada orang yang memberikan masukan, di saat kebutuhan tak mencukupi ada yang menolong memberikan makanan. Demikian juga ada saat dimana teman kekurangan sabun mandi karena belum dapat kiriman dana dari orang tua teman yang lain mau membantu membelikan sabun.

Dalam kehidupan berasrama mereka juga mau bekerja sama dalam tim. Misalnya masak bersama, doa bersama, olah raga bersama. Namun ada hal yang menarik dari hasil wawancara peneliti bahwa ada beberapa mahasiswa yang tidak atau kurang merasakan kepedulian dari sesama teman di asrama. Sebagai contoh: di saat sakit mereka tidak mendapatkan perhatian dari teman-temannya yang sebanyak itu. Rupanya ada pola pikir yang keliru; kalau kita memperha-tikan orang lain kita juga ingin diperhatikan, dan sebaliknya, kalau kita tidak diperhatikan oleh orang lain maka kita juga tidak mau memperhatikan orang lain sehingga ada yang bilang seperti ini; kepedulian yang saya rasakan bukan dari teman-teman di STT tapi dari orang luar. Menurut narasumber hal ini tentu sangat bertentangan. Seharusnya orang-orang yang belajar tentang teologi/ tentang agama yang bisa menyatakan kepedulian tapi malah orang yang diluar yang tidak belajar teologi yang memberikan perhatian.

Terkait dengan sikap peduli mahasiswa, dosen dan semua civitas akademika STT Pelita Bangsa, apakah sudah sesuai dengan apa yang tertulis dalam Filipi 2:1-8, yang antara lain berbunyi: Dalam Kristus ada nasehat, ada penghiburan kasih, ada persekutuan Roh, ada kasih mesra, dan belas kasihan (ayat 1); Hendaklah kamu sehati, sepikir, dalam satu kasih, satu jiwa, satu tujuan (ayat 2); dan janganlah tiap-tiap orang hanya memper- 
hatikan kepentingannya sendiri, tetapi kepentingan orang lain juga (ayat 4); Hendaklah kamu dalam hidupmu bersama menaruh pikiran dan perasaan yang terdapat juga dalam Kristus Yesus (ayat 5). Peneliti mendapatkan jawaban dari para narasumber bahwa menurut mereka belum semua mahasiswa dan civitas akademika mempraktikkan apa yang tertulis dalam ayat-ayat tersebut di atas. Pasti ada yang sudah melakukan tapi belum besar jumlahnya atau belum secara keseluruhan. Para dosen juga membenarkan hal itu. Ada yang menilai fifty-fifty dan itu masih dikategorikan normal karena masing-masing mempunyai kepentingan atau skala prioritas, sehingga itu masih wajar. Kecuali kalau hal itu selalu untuk kepentingan diri sendiri tentu itu konteks yang berbeda. Tapi ada dosen lain juga yang menilai sudah cukup baik namun tetap perlu ditingkatkan.

Khususnya narasumber mahasiswa mereka mengakui bahwa mereka masih perlu banyak belajar karena mereka punya ego masing-masing. Sesungguhnya mereka menyadari bahwa jika mereka melakukan apa yang tertulis dalam ayat 1 dan 2 itu sangat bagus sekali. Tetapi mereka tidak akan bisa sehati sepikir, setujuan kalau tidak punya karakter yang baik. Dalam hidup berasrama harus sehati sepikir, membangun hubungan dalam satu kasih dan satu tujuan didalam Tuhan bukan saling menyalahkan tetapi saling melengkapi, harus saling mengasihi dan merasa sepenanggungan. Ditambahkan lagi bahwa kalau kita tidak sehati sepikir, punya tujuan yang berbeda maka sangat sulit untuk membangun kekristenan secara utuh. Kita harus punya pikiran Kristus yang saling membangun dan saling menegur. Itu tandanya kita peduli satu sama lain. Ada satu ungkapan yang menurut peneliti baik untuk ditiru yang disampaikan oleh salah satu narasumber yang berbunyi demikian: Lebih baik saya menyoroti keunggulan, kebisaan, keluarbiasaan orang lain daripada menyoroti keegoisan mereka. Mereka itu berarti masih dalam proses. Kita harus tetap belajar untuk serupa dengan Kristus.

Dari hasil penelitian di lapangan peneliti menemukan data-data yang terkait dengan strategi yang diperlukan untuk membangun karakter peduli diantara sesama mahasiswa STT Pelita Bangsa. Menurut pandangan dari beberapa narasumber untuk membangun karakter peduli di antara sesama mahasiswa perlu membuat kegiatan-kegiatan yang sifatnya membangun kebersamaan, misalnya mahasiswa diterjunkan melayani bersamasama, mengadakan reatret bersama, mengadakan seminar tentang peduli sebulan sekali dan kegiatan kebersamaan lainnya seperti outbond, makan bersama, atau olah raga bersama. Hal ini bisa menolong terjadinya pendekatan sehingga mereka bisa membangun sebuah komunitas yang di dalamnya bisa saling menerima satu dengan yang lain dan bisa terjadi saling berbagi, memecahkan masalah secara bersama-sama. Menurut salah satu narasumber, yaitu mahasiswa, ia berpendapat bahwa strategi yang diperlukan untuk membangun karakter peduli dikampus STT Pelita Bangsa, dan lebih khusus di antara mahasiswa, adalah dengan keteladanan dari para pemimpin. Ada juga yang mengusulkan untuk dibuatkan semacam peraturan-peraturan, seperti contoh membatasi mahasiswa dalam penggunaan bahasa dari suku masing-masing. Kemudian hal yang tidak kala penting yang mereka sampaikan adalah pengadaan ruang khusus untuk ruangan konseling. 


\section{Pembahasan}

Berdasarkan hasil wawancara dengan narasumber terutama mahasiswa, peneliti menemukan data-data yang terkait dengan penelitian ini di antaranya ialah cara membangun karakter peduli terhadap sesama di antara mahasiswa STT Pelita Bangsa. Melalui penelitian ini terungkap bahwa sebenarnya sudah ada beberapa program kegiatan yang dilaksanakan yang tujuan awalnya hanya untuk membangun kebersamaan tetapi tanpa disadari kegiatan-kegiatan tersebut juga sudah dapat membangun karakter peduli diantara sesama mahasiswa. Seperti kegiatan makan bersama, berdoa bersama, olah raga bersama, out bond, reatret, pemuridan, mission trip dll. Menurut beberapa narasumber ini adalah bagian dari strategi untuk membangun karakter peduli. Tetapi ada beberapa hal yang ditemukan dan bisa untuk melengkapi strategi yang sudah ada yaitu pertama diperlukan model atau keteladanan dari para pemimpin, kedua perlu dibuatkan semacam peraturan-peraturan yang jelas dan tertulis misalnya dilarang menggunakan bahasa daerah di area kampus, dan yang ketiga pengadaan ruangan khusus untuk konseling.

Selain itu, terkait dengan karakter peduli terhadap sesama di antara mahasiswa sesuai dengan apa yang tertulis dalam Filipi 2:1-8, yang antara lain berbunyi: dalam Kristus ada nasihat, ada penghiburan kasih, ada persekutuan Roh, ada kasih mesra, dan belas kasihan (ayat1); Hendaklah kamu sehati, sepikir, dalam satu kasih, satu jiwa, satu tujuan (ayat 2); dan janganlah tiap-tiap orang hanya memperhatikan kepentingannya sendiri, tetapi kepentingan orang lain juga (ayat 4); Hendaklah kamu dalam hidupmu bersama menaruh pikiran dan perasaan yang terdapat juga dalam Kristus Yesus (ayat 5); ternyata peneliti mendapatkan jawaban dari para narasumber, bahwa belum semua mahasiswa dan civitas akademika mempraktikkan apa yang tertulis dalam ayat-ayat tersebut di atas. Pasti ada yang sudah melakukan tapi belum besar jumlahnya atau belum secara keseluruhan. Para dosen yang juga menjadi narasumber membenarkan hal itu. Menurut mereka bahwa ada beberapa faktor yang memengaruhi karakter peduli terhadap sesama di antara mahasiswa STT Pelita Bangsa antara lain: belum bisa menerima diri sendiri, belum memiliki pengenalan yang benar akan Kristus, dan perbedaan suku. Diperlukan suatu strategi yang dapat dipakai untuk membangun dan meningkatkan rasa kepedulian mahasiswa kepada teman-temannya dan bahkan orang lain.

\section{Kesimpulan}

Berdasarkan temuan penelitian, kesimpulan dalam penelitian ini adalah sebagai berikut: Membangun karakter peduli diantara sesama mahasiswa di kampus STT Pelita Bangsa ini sangatlah penting karena dapat meningkatkan seluruh kegiatan yang ada di STT Pelita Bangsa, baik itu dalam proses belajar mengajar di kelas ataupun di luar proses belajar mengajar. Dengan memiliki karakter peduli terhadap sesama maka mahasiswa tentu akan merasa lebih nyaman dalam hidup berdampingan satu dengan yang lain sekalipun berasal dari suku dan latar belakang yang berbeda satu sama lain. Sebagaimana yang tertulis dalam kitab Filipi 2:1-8, dalam Kristus ada nasihat, ada penghiburan kasih, ada persekutuan Roh, ada kasih mesra, dan belas kasihan (ayat1); Hendaklah kamu sehati, sepikir, dalam satu kasih, satu jiwa, satu tujuan (ayat 2); dan janganlah tiap-tiap orang hanya memperhatikan 
kepentingannya sendiri, tetapi kepentingan orang lain juga (ayat 4); Hendaklah kamu dalam hidupmu bersama menaruh pikiran dan perasaan yang terdapat juga dalam Kristus Yesus (ayat 5); di sini para mahasiswa dapat belajar untuk hidup sesuai dengan apa yang dikatakan firman Tuhan. Memiliki kerendahan hati dan mau berbagi hidup dengan orang lain sebagaimana yang Kristus teladankan.

Ada beberapa program yang dilaksanakan yang merupakan bagian dari strategi, seperti kegiatan-kegiatan yang bersifat kebersamaan. Tetapi ada hal baru yang ditemukan dan bisa untuk melengkapi strategi yang sudah ada yaitu pertama diperlukan model atau keteladanan dari para pemimpin, kedua perlu dibuatkan semacam peraturan-peraturan yang jelas dan tertulis, ketiga pengadaan ruang khusus untuk ruangan konseling. Dengan adanya strategi ini tentu akan berdampak positif bagi mahasiswa maupun pada civitas akademika dimana antara satu dengan yang lain akan saling memperhatikan, saling memberi dorongan dan saling mengasihi dan dengan demikian pasti akan terjalin kerja sama satu dengan yang lain. Pada akhirnya nama Tuhan di permuliakan di kampus STT Pelita Bangsa.

\section{Ucapan Terima Kasih}

Terima kasih kepada pihak sekolah dan Yayasan yang menaungi Sekolah Tinggi Teologi Pelita Bangsa, Jakarta, yang telah memberikan dana hibah penelitian untuk melakukan penelitian ini hingga selesai. Terima kasih juga untuk ibu Novie Deisy Pasuhuk yang telah menjadi rekan dalam penelitian ini, mengoleksi data dari lapangan dan menganalisisnya. Terima kasih juga kepada reviewer penelitian ini, David Samiyono, yang telah memberikan banyak koreksi demi mendapatkan hasil yang lebih baik.

\section{Referensi}

Anonimus. Alkitab Penuntun Hidup Berkelimpahan, Malang: Gandum Mas, 2014.

Bibleworks7.

Bungin, Burhan. Metode Penelitian Kualitatif, Jakarta: PT Raja Grafindo Persada, 2004.

Foulkes, F. "Filipi" dalam: Tafsiran Alkitab Masa Kini 3: Matius - Wahyu, Jakarta: Yayasan Komunikasi Bina Kasih/OMF, 1999.

Hakh, Samuel Benyamin. Perjanjian Baru, Sejarah, Pengantar dan Pokok-Pokok Teologisnya, Bandung: Bina Media Informasi, 2010.

Kementrian Pendidikan Nasional: Badan Penelitian dan Pengembangan Pusat Kurikulum dan Perbukuan. Panduan Pelaksanaan Pendidikan Karakter, Jakarta: 2011.

Kubo, Sakae. A Reader's Greek - English Lexicon Of The New Testament, Michigan:

Andrews Univercity Press, 1973.

Listyarti, Retno. Pendidikan Karakter Dalam Metode Aktif, Inovatif dan Kreatif, Jakarta: Esensi, 2012.

Moleong, Lexy J. Metode Penelitian Kualitatif, Bandung: Remaja Rosdakarya, 2009.

Samani, Muchlas dan Hariyanto. Konsep dan Model Pendidikan Karakter, Jakarta: Rosda Jaya, 2015.

Samarenna, Desti, and Harls Evan R Siahaan. "Memahami Dan Menerapkan Prinsip Kepemimpinan Orang Muda Menurut 1 Timotius 4:12 Bagi Mahasiswa Teologi." BIA': Jurnal Teologi dan Pendidikan Kristen Kontekstual 2, no. 1 (2019): 1-13. http://www.jurnalbia.com/index.php/bia.

Siahaan, Harls Evan. "Karakteristik Pentakostalisme Menurut Kisah Para Rasul." DUNAMIS (Jurnal Teologi dan Pendidikan Kristiani) 2, no. 1 (2017): 12-28. 
Sugiyono. Metode Penelitian Kombinasi (Mixed Methode), Bandung: Alfabeta, 2011. Sugiyono. Metode penelitian kuantitatif, kualitatif dan R\&D, Bandung: ALFABETA, 2011.

Sutanto, Hasan. Perjanjian Baru Interlinear Yunani-Indonesia dan Konkordansi Perjanjian Baru, Jakarta: Lembaga Alkitab Indonesia, 2006.

Suwondo, Chandra. Karakter Keindahan Sejati Dari Manusia, Jakarta: Metanoia, 2007. Tim Redaksi. Kamus Besar Bahasa Indonesia Pusat Bahasa, Jakarta: Gramedia, 2013. Wirartha, I. Made. Pedoman Penulisan Usulan Penelitian, Skripsi, dan Tesis, Yogyakarta: Andi, 2006. 